\title{
Pennicitrinone $D$, a new citrinin dimer from the halotolerant fungus Penicillium notatum B-52
}

\author{
Zhi-Hong Xin ${ }^{1,2}$, Wen-Liang Wang ${ }^{1}$, Ya-Peng Zhang ${ }^{1}$, Hua Xie ${ }^{3}$, Qian-Qun Gu ${ }^{1}$ and Wei-Ming Zhu ${ }^{1}$
}

The Journal of Antibiotics (2009) 62, 225-227; doi:10.1038/ja.2009.12; published online 13 March 2009

Keywords: citrinin dimers; cytotoxic metabolite; halotolerant fungus; Penicillium notatum

\begin{abstract}
Halotolerant microorganisms are considered to be extreme microbes because they thrive in high-salt environments, such as marine, salt lake, soda lake, the Dead Sea, salt field, etc. ${ }^{1,2}$ It has been postulated that extreme environments, such as high-salt could awaken some silent genes and activate some unique biosynthesis pathways and, thus, make it possible to produce structurally unique and biologically active secondary metabolites. ${ }^{3,4}$ In the course of our search for new bioactive compounds from halotolerant fungi, ${ }^{5-8}$ a fungal strain, B-52, identified as Penicillium notatum, was observed to produce cytotoxic metabolites against the mouse temperature-sensitive $c d c 2$ mutant cell line, tsFT210. This strain was isolated from salt sediments collected in Qinghai Lake, Qinghai, China. Bioassay-guided fractionation led to the identification of a new citrinin dimer, pennicitrinone D (1), along with three known compounds, pennicitrinone A (2), ${ }^{9}$ citrinin $(3)^{10-12}$ and mycophenolic acid (4) (Figure 1). ${ }^{13,14}$
\end{abstract}

\section{MATERIALS AND METHODS}

\section{General experimental procedures}

Optical rotations were obtained on a JASCO P-1020 digital polarimeter (JASCO, Tokyo, Japan). UV spectra were recorded on a Beckmen DU 640 spectrophotometer (Beckman Coulter, Beijing, China). IR spectra were taken on a Nicolet Nexus 470 spectrophotometer (Thermo Scientific, Beijing, China) in $\mathrm{KBr}$ disks. 1D- and 2D-NMR spectra were recorded on a JEOL JNM-ECP 600 spectrometer (JEOL Ltd, Beijing, China) using tetramethylsilane as the internal standard, and chemical shifts were recorded as $\delta$-values. Electrospray ionization mass spectrometry was measured on a Q-Tof Ultima Global GAA076 LC mass spectrometer (Waters Asia, Ltd, Singapore). Semi-preparative HPLC was performed on a SHIMAD-ZU LC-6AD liquid chromatograph with an SPD-M10A vp diode array detector (both from Shimadzu International Trading Co. Ltd, Beijing, China).

\section{Strain}

The fungus, P. notatum B-52, was isolated from salt sediments collected from the Qinghai Lake, Qinghai Province of China. It was identified according to its morphological characteristics and preserved in the China Center for Type Culture Collection (No. CCTCC M205047). The working strain was prepared on potato dextrose agar slants containing $10 \% \mathrm{NaCl}$ and stored at $4{ }^{\circ} \mathrm{C}$.

\section{Fermentation}

The producing strain, $P$. notatum B-52, was inoculated into a $500-\mathrm{ml}$ conical flask containing $100 \mathrm{ml}$ of the liquid medium composed of mannitol $\left(20 \mathrm{gl}^{-1}\right)$, maltose $\left(20 \mathrm{gl}^{-1}\right)$, glutamine $\left(10 \mathrm{gl}^{-1}\right)$, glucose $\left(10 \mathrm{gl}^{-1}\right)$, yeast extract $\left(3 \mathrm{gl}^{-1}\right), \mathrm{NaCl}\left(80 \mathrm{gl}^{-1}\right), \mathrm{KCl}\left(10 \mathrm{gl}^{-1}\right), \mathrm{MgSO}_{4}\left(10 \mathrm{gl}^{-1}\right)$ and seawater (adjusted to pH 6.5 before sterilization) and cultured at $28^{\circ} \mathrm{C}$ for $48 \mathrm{~h}$ on a rotary shaker at 120 r.p.m. The seed culture was transferred into two-hundred 500-ml conical flasks ( $150 \mathrm{ml}$ per flask), and fermentation was carried out at $28^{\circ} \mathrm{C}$ for 10 days with an agitation rate of 120 r.p.m.

\section{Extraction and isolation}

The fermented whole broth (301) of P. notatum B-52 was filtered through a cheesecloth to separate into filtrate and mycelia. The filtrate was concentrated under reduced pressure to approximately a quarter of the original volume and then extracted thrice with ethyl acetate. The mycelia were extracted thrice with acetone. The acetone solution was concentrated under reduced pressure to afford an aqueous solution. The aqueous solution was extracted thrice with ethyl acetate. The combined ethyl acetate extract was concentrated under reduced pressure to give a crude extract $(30 \mathrm{~g})$. The crude extract was separated into five fractions on a flash silica gel column using a step gradient elution of $n$-hexane-EtOAc and then of EtOAc-MeOH. Fractions $2(1.5 \mathrm{~g})$ and $3(1.3 \mathrm{~g})$ showed cytotoxicity against tsFT210 cells. Fraction 2 was further separated into four sub-fractions over a silica gel column eluted with $n$-hexane-EtOAc (20:80). Sub-fractions 2-3 (45 mg) and 2-4 $(50 \mathrm{mg})$ were separated by semi-preparative HPLC on a Shin-pak octadecylsilyl column using $\mathrm{MeOH}-\mathrm{H}_{2} \mathrm{O}$ (50:50 and 70:30, respectively) as an eluting solvent to give $3(22 \mathrm{mg})$ and $4(36 \mathrm{mg})$, respectively. Fraction $4(2 \mathrm{~g})$ was further purified into three sub-fractions by vacuum silica gel column chromatography using a step gradient elution of $\mathrm{CHCl}_{3}-\mathrm{MeOH}$. Sub-fractions 4-2 (350 mg) were subjected to chromatography over Sephadex LH-20 eluted with $\mathrm{CHCl}_{3}-\mathrm{MeOH}$ (1:1), and the obtained fraction was further purified by

${ }^{1}$ Key Laboratory of Marine Drugs, Chinese Ministry of Education; School of Medicine and Pharmacy, Ocean University of China, Qingdao, PR China; ${ }^{2}$ Department of Food Quality and Safety, College of Food and Technology, Nanjing Agriculture University, Nanjing, PR China and ${ }^{3}$ State Key Laboratory of Drug Research, Shanghai Institute of Materia Medica, Chinese Academy of Sciences, Shanghai, PR China

Correspondence: Professor W-M Zhu, Key Laboratory of Marine Drugs, Chinese Ministry of Education, School of Medicine and Pharmacy, Ocean University of China, Qingdao, Shandong 266003, China.

E-mail: weimingzhu@ouc.edu.cn

Received 28 August 2008; accepted 28 January 2009; published online 13 March 2009 


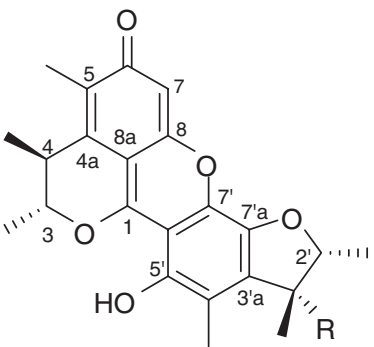

1: $\mathrm{R}=\mathrm{OH}, \quad 2: \mathrm{R}=\mathrm{H}$<smiles>CC1=C2C(=CO[C@H](C)[C@H]2C)C(O)=C(C(=O)O)C1=O</smiles>

3<smiles>COc1c(C)c2c(c(O)c1C/C=C(\C)CCC(=O)O)C(=O)OC2</smiles>

4

Figure 1 Structures of compounds 1-4.

Table $1{ }^{1} \mathrm{H}$ and ${ }^{13} \mathrm{C}$ NMR (600 and $150 \mathrm{MHz}$ ) data for 1 and $2^{\mathrm{a}}$

\begin{tabular}{|c|c|c|c|c|}
\hline \multirow[b]{2}{*}{ Position } & \multicolumn{2}{|c|}{1} & \multicolumn{2}{|l|}{2} \\
\hline & ${ }^{1} \mathrm{H}(\mathrm{J}$ in $\mathrm{Hz})$ & ${ }^{13} \mathrm{C}$ & ${ }^{1} H(J$ in $H z)$ & ${ }^{13} \mathrm{C}$ \\
\hline 1 & - & $156.0 \mathrm{~s}$ & - & $155.4 \mathrm{~s}$ \\
\hline 3 & 4.89 q (6.0) & $82.9 \mathrm{~d}$ & $4.98 \mathrm{q}(6.8)$ & $82.3 \mathrm{~d}$ \\
\hline 4 & $2.97 \mathrm{q}(7.3)$ & $34.8 \mathrm{~d}$ & $3.13 \mathrm{q}(7.3)$ & $35.0 \mathrm{~d}$ \\
\hline $4 a$ & - & $130.0 \mathrm{~s}$ & - & $130.8 \mathrm{~s}$ \\
\hline 5 & - & $131.8 \mathrm{~s}$ & - & $131.9 \mathrm{~s}$ \\
\hline 6 & - & $183.8 \mathrm{~s}$ & - & $184.4 \mathrm{~s}$ \\
\hline 7 & $6.24 \mathrm{~s}$ & $103.5 \mathrm{~d}$ & $6.37 \mathrm{~s}$ & $103.3 \mathrm{~d}$ \\
\hline 8 & - & $157.4 \mathrm{~s}$ & - & $158.0 \mathrm{~s}$ \\
\hline $8 a$ & - & $99.6 \mathrm{~s}$ & - & $100.1 \mathrm{~s}$ \\
\hline 3-Me & $1.28 \mathrm{~d}(6.0)$ & $18.7 \mathrm{q}$ & $1.45 \mathrm{~d}(6.8)$ & $18.9 \mathrm{q}$ \\
\hline 4-Me & $1.29 \mathrm{~d}(7.3)$ & $19.1 \mathrm{q}$ & $1.32 \mathrm{~d}(7.3)$ & $19.1 \mathrm{q}$ \\
\hline 5-Me & $1.91 \mathrm{~s}$ & $10.4 \mathrm{q}$ & $2.12 \mathrm{~s}$ & $10.7 \mathrm{q}$ \\
\hline 2 & 5.07 q (6.0) & $89.6 \mathrm{~d}$ & $4.62 \mathrm{dq}(4.1,6.4)$ & $88.0 \mathrm{~d}$ \\
\hline 3 & - & $80.7 \mathrm{~s}$ & $3.17 \mathrm{dq}(4.1,6.9)$ & $44.6 \mathrm{~d}$ \\
\hline $3 a$ & - & $140.5 \mathrm{~s}$ & - & $139.2 \mathrm{~s}$ \\
\hline 4 & - & $117.0 \mathrm{~s}$ & - & $116.4 \mathrm{~s}$ \\
\hline 5 & - & $146.8 \mathrm{~s}$ & - & $147.4 \mathrm{~s}$ \\
\hline 6 & - & $101.7 \mathrm{~s}$ & - & $102.2 \mathrm{~s}$ \\
\hline 7 & - & $135.8 \mathrm{~s}$ & - & $135.8 \mathrm{~s}$ \\
\hline $7 a$ & - & $138.1 \mathrm{~s}$ & - & $137.8 \mathrm{~s}$ \\
\hline 2-Me & $1.55 \mathrm{~d}(6.0)$ & $14.5 \mathrm{q}$ & $1.42 \mathrm{~d}(6.4)$ & $20.9 q$ \\
\hline 3-Me & $1.43 \mathrm{~s}$ & $21.1 \mathrm{q}$ & $1.34 \mathrm{~d}(6.9)$ & $18.8 \mathrm{q}$ \\
\hline 4-Me & $2.32 \mathrm{~s}$ & $9.4 \mathrm{q}$ & $2.21 \mathrm{~s}$ & $11.5 \mathrm{q}$ \\
\hline $3-\mathrm{OH}$ & 4.98 & - & - & - \\
\hline $5-\mathrm{OH}$ & 7.99 & - & 8.36 & - \\
\hline
\end{tabular}

Abbreviations: COSY, correlated spectroscopy; ${ }^{13} \mathrm{C}$ NMR, carbon-13 nuclear magnetic resonance; DEPT, distortionless enhancement by polarization transfer; HMQC, heteronuclear multiple quantum coherence; HMBC, heteronuclear multiple bond coherence. aThe assignments were based on DEPT, ${ }^{1} \mathrm{H}^{1}{ }^{1} \mathrm{H}$ COSY, HMQC and HMBC experiments, and recorded in $\mathrm{CDCl}_{3}$.

preparative HPLC (60\% MeOH as the eluant) to yield compound 1 (9 mg). By the same procedure, compound $2(16 \mathrm{mg})$ was obtained from the sub-fraction 4-3 (750 mg).

\section{Biological assay}

Active fractions were assayed using the methylthiazoletetrazolium (MTT) method ${ }^{15}$ with the mouse temperature-sensitive $c d c 2$ mutant cell line, tsFT210. Compounds 1-4 were evaluated for cytotoxic effects on P388 and HL-60 cell lines using the MTT method and on A-549 and BEL-7402 cell lines using the sulforhodamine B (SRB) method. ${ }^{16}$

In the MTT assay, cell lines were grown in RPMI-1640 supplemented with 10\% fetal bovine serum under a humidified atmosphere of $5 \% \mathrm{CO}_{2}$ and $95 \%$ air at $37^{\circ} \mathrm{C}\left(\operatorname{tsFT} 210\right.$ cell line at $\left.32^{\circ} \mathrm{C}\right)$. Cell suspensions of $200 \mu \mathrm{l}$, at a density of $5 \times 10^{4}$ cell $\mathrm{ml}^{-1}$, were plated in 96-well microtiter plates and incubated for $24 \mathrm{~h}$ at the above conditions. Next, $2 \mu \mathrm{l}$ of the test compounds in DMSO at different concentrations was added to each well and further incubated for $72 \mathrm{~h}$ under the same conditions. MTT solution ( $20 \mu \mathrm{l}, 5 \mathrm{mg} \mathrm{ml}^{-1}$ in IPMI- 1640 medium) was added to each well and incubated for $4 \mathrm{~h}$. Old medium $(150 \mu \mathrm{l})$ containing MTT was then gently replaced by DMSO and pipetted to dissolve any formazan crystals that had formed. Absorbance was then determined on a Spectra Max Plus plate reader at $540 \mathrm{~nm}$.

In the SRB assay, 200- $\mu$ l portions of cell suspension were plated in 96-well plates at a density of $2 \times 10^{5} \mathrm{cell} \mathrm{ml}^{-1}$. Then, $2 \mu \mathrm{l}$ of the test solutions (in $\mathrm{MeOH}$ ) was added to each well and the culture was further incubated for $24 \mathrm{~h}$. The cells were fixed with 12\% TCA and the cell layer was stained with $0.4 \%$ SRB. The absorbance of the SRB solution was measured at $515 \mathrm{~nm}$. Doseresponse curves were generated, and the $\mathrm{IC}_{50}$ values, the concentration of compound required to inhibit cell proliferation by $50 \%$, were calculated from the linear portion of log dose-response curves.

Compound 1: yellow amorphous powder; $[\alpha]_{\mathrm{D}}^{17}+111.1$ ( 1 0.16, $\mathrm{CHCl}_{3}$ ); high-resolution electrospray ionization mass spectrometry (HRESI-MS) $\mathrm{m} / \mathrm{z} 397.1624$ (calcd for $\mathrm{C}_{23} \mathrm{H}_{25} \mathrm{O}_{6}, 397.1651$ ); UV $\left(\mathrm{CHCl}_{3}\right) \lambda_{\max }(\log \varepsilon) \mathrm{nm} 204$ (4.85), 227 (4.93), 272 (4.43), 436 (4.38); UV (MeOH) $\lambda_{\max }(\log \varepsilon) \mathrm{nm} 202$ (4.54), 225 (4.58), 270 (4.23), 274 (4.31), 430 (4.19); IR $v_{\max } \mathrm{cm}^{-1}$ (KBr) 3450, 2972, 2930, $1616,1508,1447,1360,1189,1136,1023,890,838 ;{ }^{1} \mathrm{H}\left(\mathrm{CDCl}_{3}\right.$, $600 \mathrm{MHz})$ and ${ }^{13} \mathrm{C}\left(\mathrm{CDCl}_{3}, 150 \mathrm{MHz}\right)$, see Table 1.

Compound 2: yellow amorphous powder; $[\alpha]_{\mathrm{D}}^{17}+106.9$ (c 0.36 , $\mathrm{CHCl}_{3}$ ); HRESI-MS $m / z 381.1673$ (calcd for $\mathrm{C}_{23} \mathrm{H}_{25} \mathrm{O}_{5}, 381.1702$ ); $\mathrm{UV}\left(\mathrm{CHCl}_{3}\right) \lambda_{\max }(\log \varepsilon) \mathrm{nm} 202$ (3.46), 226 (3.57), 278 (4.35), 426 (4.24); UV (MeOH) $\lambda_{\max }(\log \varepsilon) \mathrm{nm} 201$ (4.60), 225 (4.50), 267 (4.46), 277 (4.47), 421 (4.40); IR $v_{\max } \mathrm{cm}^{-1}(\mathrm{KBr}) 3440,2966,2909,1617$, $1509,1431,1324,1281,1138,1042,984,884 ;{ }^{1} \mathrm{H}\left(\mathrm{CDCl}_{3}, 600 \mathrm{MHz}\right)$ and ${ }^{13} \mathrm{C}\left(\mathrm{CDCl}_{3}, 150 \mathrm{MHz}\right)$, see Table 1 .

Pennicitrinone D (1) was obtained as a yellow amorphous powder. Its molecular formula was determined as $\mathrm{C}_{23} \mathrm{H}_{24} \mathrm{O}_{6}$ based on HRESIMS at $m / z 397.1624[\mathrm{M}+\mathrm{H}]^{+}($calcd 397.1651$)$. The diagnostic IR peaks were observed for hydroxyl, conjugated carbonyl and benzene ring at 3450,1616 and $1508 \mathrm{~cm}^{-1}$, respectively. 1D-NMR spectra of $\mathbf{1}$ displayed six methyls, three $\mathrm{sp}^{3}$ methines (two oxygenated), one $\mathrm{sp}^{2}$ methine, one carbonyl, $11 \mathrm{sp}^{2}$ quaternary carbons and one $\mathrm{sp}^{3}$ oxygenated quaternary carbon (Table 1). Except for an oxygenated quaternary carbon signal $\left(\delta_{\mathrm{OH}} 4.98\right.$ and $\left.\delta_{\mathrm{C}} 80.7\right)$ instead of a methine signal $\left(\delta_{\mathrm{H}} 3.17\right.$ and $\left.\delta_{\mathrm{C}} 44.6\right)$, the ${ }^{1} \mathrm{H}$ - and ${ }^{13} \mathrm{C}$-NMR spectra of 1 were similar to those of $2^{9}$, suggesting that they shared the same molecular skeleton. Further comparison of the ${ }^{13} \mathrm{C}-\mathrm{NMR}$ spectra of 1 with that of 2 revealed $+1.6,+36.1,+1.3,+2.3,-6.4$ and -2.1 p.p.m. of chemical shift effects for C-2', C-3', C-3'a, C-3'-Me, C-2'-Me and C-4'-Me, respectively, showing that $\mathbf{1}$ is a $3^{\prime}$-hydroxy derivative of $\mathbf{2}$. This conclusion was further confirmed by ${ }^{1} \mathrm{H}_{-}{ }^{1} \mathrm{H}$ COSY, heteronuclear 


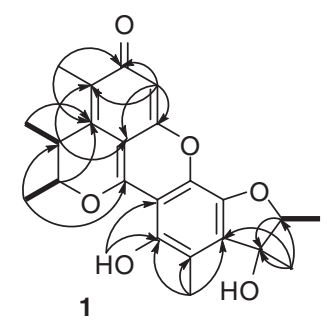

- ${ }^{1} \mathrm{H}-{ }^{-1} \mathrm{H}$ COSY

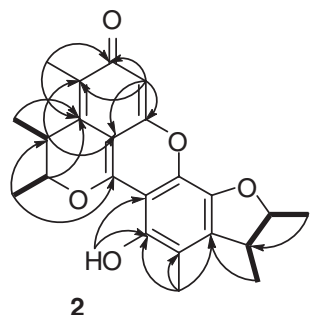

2

$\frown \mathrm{HMBC}$

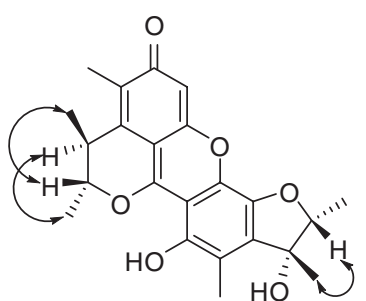

1

$\checkmark$ NOESY

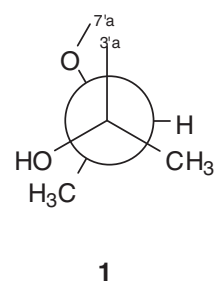

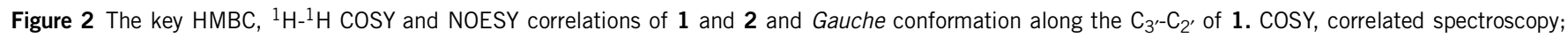
NOESY, nuclear overhauser enhanced and exchange spectroscopy; HMBC, heteronuclear multiple bond coherence.<smiles>CC1=C2C(=CO[C@@H](C)[C@@H]2C)C(O)=C(C(=O)O)C1=O</smiles>

3

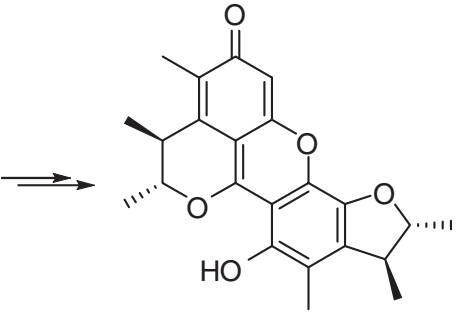

2

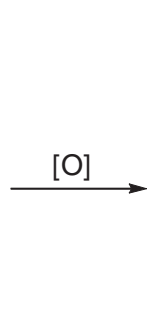<smiles></smiles>

1

Scheme 1 The postulated biosynthesis of 1 .

multiple quantum coherence (HMQC), NOESY and heteronuclear multiple bond coherence (HMBC) experiments (Figure 2). The upfield shifts of C-2'-Me and C- $4^{\prime}$-Me were caused by the $\gamma$-gauche effect and by the stereospecific blockade of $3^{\prime} \alpha-\mathrm{OH}$, respectively. The absolute configuration of $\mathbf{1}$ was determined as shown by the NOE correlations and further by comparing the $[\alpha]_{\mathrm{D}}$ value, +111.1 , with that of $2,+106.9$ and a possible biogenic pathway (Scheme 1). Compound $\mathbf{1}$ is most likely produced from the oxidation of $\mathbf{2}$ that is produced by a Diels-Alder reaction of 3.,17 Thus, the structure of $\mathbf{1}$ was elucidated as $\left(3^{\prime} R\right)-3^{\prime}$-hydroxypennicitrinone A.

According to ${ }^{1} \mathrm{H}-{ }^{1} \mathrm{H}$ COSY, HMQC and HMBC experiments, ${ }^{13} \mathrm{C}$ NMR data of 3-Me, $2^{\prime}$-Me and $3^{\prime}$-Me of 2 in the literature ${ }^{9}$ should be interchanged as 19.1, 21.0 and 18.8 p.p.m., respectively.

The cytotoxicity of compounds $\mathbf{1 - 4}$ was evaluated against P388 and HL-60 cell lines by the MTT method, ${ }^{15}$ and against BEL-7402 and A-549 cell lines by the SRB method. ${ }^{16}$ Compound 2 showed weak cytotoxicity against P388 and BEL-7402 cells with $\mathrm{IC}_{50}$ values of 25 and $16 \mu \mathrm{M}$, respectively. Compound 4 exhibited moderate cytotoxicity against A-549 cells with an $\mathrm{IC}_{50}$ value of $0.95 \mu \mathrm{M}$, whereas compounds $\mathbf{1}$ and $\mathbf{3}$ were inactive.

\section{ACKNOWLEDGEMENTS}

This work was supported by the National Natural Science Foundation of China (No. 30470196, 30670219 and 30572246). The fungus strain, P. notatum B-52, was identified by Professor Li Tian, First Institute of Oceanography, State Oceanic Administration of China.

1 Kamekura, M. Diversity of extremely halophilic bacteria. Extremophiles 2, 289-295 (1998).
2 Aguilar, A., Ingemansson, T. \& Magnien, E. Extremophile microorganisms as cell factories: support from the European Union. Extremophiles 2, 367-373 (1998).

3 Koch, A. L. Genetic response of microbes to extreme challenges. J. Theor. Biol. 160, 1-21 (1993).

4 Méjanelle, L., Lòpez, J. F., Gunde-Cimerman, N. \& Grimalt, J. O. Ergosterol biosynthesis in novel melanized fungi from hypersaline environments. J. Lipid. Res. 42, 352-358 (2001).

5 Lu, Z. Y. et al. Citrinin dimers from the halotolerant fungus Penicillium citrinum B-57. J. Nat. Prod. 71, 543-546 (2008).

6 Wang, W. L. et al. Two new cytotoxic quinone type compounds from the halotolerant fungus Aspergillus variecolor. J. Antibiot. 60, 603-607 (2007).

7 Wang, W. L. et al. Isoechinulin-type alkaloids, variecolorin A-L, from halotolerant Aspergillus variecolor. J. Nat. Prod. 70, 1558-1564 (2007).

8 Wang, W. L. et al. Three novel, structurally unique spirocyclic alkaloids from the halotolerant B-17 fungus strain of Aspergillus variecolor. Chem. Biodivers. 4, 2913-2919 (2007).

9 Wakana, D. et al. New citrinin derivatives isolated from Penicillium citrinum. J. Nat. Med. 60, 279-284 (2006).

10 Rödel, T. \& Gerlach, H. Enantioselective synthesis of the polyketide antibiotic (3R,4S)(-)-citrinin. Liebigs Ann. 1995, 885-888 (1995).

11 Rodig, O. R., Shiro, M. \& Fernando, Q. The crystal and molecular structure of citrinin. J. Chem. Soc. Chem. Commun 1553-1554 (1971).

12 Chien, M. M., Schiff, P. L. Jr, Slatkin, D. J. \& Knapp, J. E. Metabolites of Aspergilli. III. The isolation of citrinin, dihydrocitrinone and sclerin from Aspergillus carneus. Lloydia 40, 301-302 (1977).

13 Nelson, P. H., Eugui, E., Wang, C. C. \& Allison, A. C. Synthesis and immunosuppressive activity of some side-chain variants of mycophenolic acid. J. Med. Chem. 33, 833-888 (1990).

14 Anderson, W. K., Boehm, T. L., Makara, G. M. \& Swann, R. T. Synthesis and modeling studies with monocyclic analogues of mycophenolic acid. J. Med. Chem. 39, 46-55 (1996).

15 Mosmann, T. Rapid colorimetric assay for cellular growth and survival: application to proliferation and cytotoxicity assays. J. Immunol. Methods 65, 55-63 (1983).

16 Skehan, P. et al. New colorimetric cytotoxicity assay for anticancer drug screening. J. Natl Cancer Inst. 82, 1107-1112 (1990).

17 Clark, B. R., Capon, R. J., Lacey, E., Tennant, S. \& Gill, J. H. Citrinin revisited: from monomers to dimers and beyond. Org. Biomol. Chem. 4, 1520-1528 (2006). 